\title{
Efektivitas Model Pembelajaran Kumon terhadap Peningkatan Hasil Belajar Matematika Siswa Kelas VIII
}

\author{
Halidin \\ Pendidikan Matematika, Universitas Sembilanbelas November Kolaka, Indonesia \\ email: halidinidin@yahoo.co.id
}

\begin{abstract}
Abstrak
Penelitian ini merupakan penelitian eksperimen dalam bentuk Pre-Eksperimental Design dengan tujuan 1) untuk mengetahui hasil belajar Pretest matematika siswa sebelum diajar dengan model pembeljaran Kumon; 2) untuk mengetahui hasil belajar Posttest matematika siswa setelah diajar dengan model pembelajaran Kumon; 3) untuk mengetahui apakah model pembelajaran Kumon efektif terhadap peningkatan hasil belajar matematika siswa kelas VIII SMP Negeri 05 Poleang Timur dalam pengajaran kubus dan balok. Populasi dalam penelitian ini adalah seluruh siswa kelas VIII SMP Negeri 05 Poleang Timur tahun ajaran 2018/2019 yang tersebar dalam 3 kelas pararel dengan jumlah 56 siswa. Pengambilan sampel dilakukan dengan menggunakan teknik Purposive Sampling diperoleh satu kelas penelitian, yaitu kelas eksperimen. Sampel dalam penelitian ini berjumlah 18 orang. Teknik pengumpulan data ini menggunakan teknik tes dan non tes. Teknik analisis data menggunakan statistik deskriptif dan statistik inferensial. Hasil penelitian secara empiris (deskriptif) menunjukkan bahwa; 1) hasil belajar siswa sebelum diajar dengan model pembelajaran Kumon yang terdiri dari 15 orang diperoleh nilai minimum 44.60, nilai maksimum 84.90, rata-rata (mean) 67.6013, varians 177.435, dan standar deviasi 13.32049; 2) hasil belajar siswa setelah diajar dengan model pembelajaran Kumon yang terdiri dari 15 orang diperoleh nilai minimum 49.71, nilai maximum 100, rata-rata (mean) 72.9993, varians 227.327, dan standar deviasi 15.07735; 3) melalui analisis lembar observasi aktivitas guru dan aktivitas siswa pada kelas penelitian telah menunjukkan kriterian sangat aktif dengan nilai rata-rata $>80 \%$. Hasil penelitian secara inferensial dengan menggunakan uji-t telah diperoleh nilai thitung $=4,79$ dengan ttabel $=1.76$, menunjukkan bahwa HO di tolak dan $\mathrm{HI}$ diterima. Secara inferensial ini berarti bahwa model pembelajaran Kumon efektif terhadap peningkatan hasil belajar matematika siswa kelas VIII SMP Negeri 05 Poleang Timur dalam pengajaran kubus dan balok.
\end{abstract}

Kata Kunci: Efektivitas; Model Pembelajaran Kumon; Hasil Belajar Matematika Siswa.

\section{PENDAHULUAN}

Matematika dipandang sebagai bagian ilmu-ilmu dasar yang berkembang pesat baik isi maupun aplikasinya, sehingga pengajaran matematika di Sekolah merupakan prioritas dalam pembangunan pendidikan. Kurikulum 2013 siswa lebih dituntut untuk aktif, kreatif dan inovatif dalam setiap pemecahan masalah yang mereka hadapi di sekolah. Berdasarkan pengamatan secara nyata dilakukan peneliti di lapangan, pelajaran matematika masih menjadi salah satu mata pelajaran yang dianggap sulit dan menakutkan serta cenderung tidak disukai oleh sebagian besar siswa. 
Akibatnya siswa tidak memiliki kemandirian untuk berusaha memahami dan mempelajari matematika, selain itu masih banyak guru yang menggunakan model pembelajaran konvensional dengan menggunakan metode ceramah dimana guru sebagai pusat informasi menerangkan materi dan siswa duduk dengan manis mendengarkan dan mencatat materi yang disampaikan oleh guru, sehingga siswa menjadi pasif dan tidak kreatif, karena tidak ada kesempatan untuk menggali potensi dalam dirinya. Hal tersebut menyebabkan siswa kurang mandiri dan tidak memiliki kemampuan menyelesaikan masalah dengan alternatif lain karena siswa kurang memiliki kemampuan fleksibilitas Pelaksanaan pembelajaran yang dilaksanakan sampai saat ini, kesulitan dalam mempelajari matematika masih dialami oleh siswa dari seluruh jenjang. Salah satu akibat kesulitan siswa dalam mempelajari materi matematika adalah rendahnya prestasi belajar yang dicapai siswa.

Pembelajaran matematika yang dilakukan selama ini telah menjadi kebiasaan para guru menyajikan pelajaran dengan urutan sebagai berikut: 1) Diajarkan teori/definisi/teorema; 2) Diberikan contoh-contoh; 3) dan Diberikan latihan soal-soal. Soedjadi (dalam Jusman 2014:6) mengemukakan bahwa perkembangan intelektual siswa pada umumnya bergerak dari "konkret ke abstrak", maka urutan sajian seperti disebutkan di atas tidaklah tepat. Penyesuaian urutan sajian bahan ajar dengan perkembangan intelektual siswa memerlukan pemikiran yang cukup mendalam, mengingat objek kajian matematika sebenarnya adalah abstrak. Selanjutnya juga mengatakan bahwa guru matematika harus mampu mengkonkretkan atau menyederhanakan objek matematika yang abstrak agar mudah dipelajari siswa. Siswa diharapkan dapat meningkatkan hasil belajarnya.

Beberapa penelitian yang berkaitan dengan model pembelajaran kumon menunjukkan hasil yang positif terhadap hasil pembelajaran yaitu penelitian yang dilakukan oleh Anca (2015: 7) menyimpulkan bahwa penerapan model pembelajaran Kumon menghasilkan kemandirian dan prestasi belajar matematika yang lebih baik dibandingkan dengan penerapan metode ekspositori pada siswa kelas VII SMP Takhassus Nuril Anwar Loano Purworejo tahun ajaran 2015/2016; Ekan (2015: 12) menyimpulkan bahwa model pembelajaran Kumon mampu meningkatkan hasil belajar matematika siswa kelas VIII dibandingkan model pembelajaran konvensional tahun ajaran 2015/2016.

Berdasarkan hasil observasi pada tanggal 15 Mei 2019 dengan guru matematika SMP Negeri 05 Poleang Timur mengatakan bahwa SMP Negeri 05 Poleang Timur menggunakan kurikulum tingkat satuan pendidikan (KTSP) dengan model pembelajaran konvensional terdapat beberapa kelemahan model mengajar yang digunakan guru matematika di SMP Negeri 05 Poleang Timur terlihat dari proses pembelajaran yang dilaksanakan di kelas diantaranya guru kurang menggunakan model pembelajaran yang bervariasi dan hanya menggunakan model pembelajaran konvensional, sehingga siswa masih kurang termotivasi untuk belajar matematika, enggan untuk mengerjakan soal latihan, tugas atau PR, serta siswa jarang memiliki keberanian untuk bertanya atau mengungkapkan pendapatnya dikelas dan bahkan terkadang mereka mengantuk. Akibatnya tidak dapat meningkatkan prestasi belajar siswa. Hal ini terlihat dari data di SMP Negeri 05 Poleang Timur, pelajaran matematika kelas VIII SMP Negeri 05 Poleang Timur baru sedikit yang mencapai diatas kriteria ketuntasan minimal (KKM) yaitu rata-rata 73.

Berdasarkan permasalahan yang dikemukakan di atas maka perlu adanya mencari sebuah model pembelajaran yang tepat agar bisa meningkatkan aktivitas dan hasil belajar siswa. Adapun salah satu model pembelajaran yang dianggap dapat meningkatkan aktivitas dan hasil belajar siswa pada mata pelajaran matematika adalah model pembelajaran kumon. Model pembelajaran Kumon berasal dari Jepang dianggap efektif meningkatkan kemampuan matematika anak di Sekolah, karena pada model pembelajaran Kumon lebih menekankan kegiatannya pada masingmasing peserta didik, sehingga peserta didik dapat menggali potensi dirinya dan mengembangkan kemampuannya secara maksimal. Pembelajaran Kumon tidak hanya mengajarkan cara berhitung 
tetapi juga dapat meningkatkan kemampuan peserta didik untuk lebih fokus dalam mengerjakan sesuatu dan percaya diri. Sehingga memberikan dampak pada hasil belajar yang akan dicapai.

Salah satu alasan model pembelajaran Kumon efektif adalah model pembelajaran dimana dalam program pembelajarannya disesuaikan dengan kemampuan serta potensi masing-masing siswa. Dengan demikian, akan lebih mudah bagi siswa untuk mempelajarinya. Begitu teknik inti sudah dimengerti, siswa bisa langsung mempraktikannya sendiri dirumah dengan berlatih soalsoal. Bila terus berlatih, kemampuannya akan terasah. Pada model pembelajaran ini, peserta didik diberikan bimbingan secara perseorangan. Karena itu sebelum memulai pelajarannya, peserta didik diberikan tes untuk mengetahui titik pangkal yang tepat atau pengetahuan mereka terhadap materi yang diberikan. Dimana dalam pembelajaran tersebut akan dimulai dari bagian yang dapat dikerjakan siswa dengan mudah dan sedikit demi sedikit dilanjutkan ketingkat yang lebih tinggi

Adapun tujuan penelitian ini untuk mengetahui 1) hasil belajar Pretest matematika siswa sebelum diajar dengan model pembelajaran Kumon Siswa VIII SMP Negeri 05 Poleang Timur; 2) Hasil belajar Posttest matematika siswa setelah diajar dengan menggunakan model pembelajaran Kumon Siswa VIII SMP Negeri 05 Poleang Timur; 3) Peningkatan hasil belajar matematika setelah diajar dengan menggunakan model pembelajaran Kumon dalam pengajaran kubus dan balok Siswa VIII SMP Negeri 05 Poleang Timur.

\section{METODE PENELITIAN}

Dalam penelitian ini, metode yang digunakan peneliti adalah penelitian eksperimen. Penelitian ini termasuk dalam bentuk Pre- Eksperimental Design. Penelitian ini menggunakan satu kelas yaitu kelas eksperimen dengan menerapkan model pembelajaran Kumon. Penelitian eksperimen dapat diartikan sebagai metode penelitian yang digunakan untuk mencari pengaruh tertentu terhadap yang lain dalam kondisi yang terkendalikan (Sugiyono, 2015: 107).

Penelitian ini dilaksanakan di SMP Negeri 5 Poleang Timur Kelas VIII MIA semester genap pada tanggal 22 Mei hingga 27 Mei 2019 Tahun ajaran 2018/2019. Adapun Populasi dalam penelitian ini adalah semua siswa kelas VIII semester 2 SMP Negeri 5 Poleang Timur tahun pelajaran 2018/2019. Sampel dalam penelitian ini dipilih dengan menggunakan purposive sampling. Dengan memilih satu kelas sebagai kelas eksperimen yang menerapkan model pembelajaran Kumon. Sampel yang dipilih dengan teknik ini, berdasarkan pertimbangan rata-rata hasil belajar siswa kelas VIII SMP Negeri 05 Poleang Timur

Dalam penelitian ini desain yang digunakan adalah desain Pre Eksperimental dengan rancangan One-Group Pretest-Posttest Design. Teknik pengumpulan data yang digunakan dalam penelitian ini adalah teknik tes dan observasi. Sedangkan Instrumen yang akan digunakan untuk mengumpulkan data adalah instrumen tes dan lembar observasi. Instrumen tes digunakan untuk mengetahui hasil belajar siswa berupa soal pree-test dan post-test berbentuk uraian (esasy) dan lembar observasi berupa lembar observasi aktivitas siswa dan lembar observasi aktivitas guru. Sebelum instrument diberikan kepada siswa sebelumnya di uji valid dan reliabilitas.)

Teknik analisis dalam penelitian ini adalah teknik analisis deskriptif dan Inferensial. Teknik analisis deskriptif dimaksudkan untuk mendeskripsikan karakteristik variabel penelitian melalui skor rata-rata, standar deviasi, varians dan menghitung persentase ketuntasan hasil belajar siswa secara klasikal sedangkan analisis Inferensial untuk melihat pengaruh model pembelajaran terhadap hasil belajar siswa. Uji yang dilakukan antara lain:

1. Uji normalitas dengan IBM SPSS Statistic 25 melalui hasil Kolmogorov-Smirnov sebagai uji prasyarat untuk Independent Sample T-test untuk mengetahui normalitas data hasil pre-testpost-test.

2. uji-t yaitu Paired sampel t-test untuk mengetahui pengaruh strategi pembelajaran Kumon terhadap hasil belajar matematika siswa dengan melihat perbedaan nilai rata-rata hasil belajar siswa. 
3. Sebelum melakukan T-test terlebih dahulu dilakukan uji normalitas data menggunakan Kolomogorof Smirnov dan uji homogenitas menggunakan Lavene Test. Jika hasil dari uji normalitas Kolmogorof Smirnov memiliki signifikansi > 0,05 maka nilai pre-test dan posttest berdistribusi normal. Namun jika signifikansi $<0,05$ maka nilai pre-test dan post-test tidak normal. Setelah memenuhi persyaratan normalitas kemudian dilakukan uji T-test (Paired Sample T-test $t$ ). Jika signifikansi hasil Paired Sample T-test dengan thitung $\geq$ ttabel maka tolak Ho artinya model pembelajaran kumon efektif terhadap hasil belajar matematika siswa.

\section{HASIL DAN PEMBAHASAN}

Nilai rata-rata persentase keaktifan guru dalam melaksanakan model pembelajaran kumon yaitu $84.75 \%$. Persentase tersebut menunjukkan bahwa dalam pelaksanaan pembelajaran, guru telah mengikuti langkah-langkah pembelajaran Kumon sesuai dengan sintaknya. Hal ini menunjukkan bahwa guru sudah mampu melaksanakan proses pembelajaran tersebut sesuai dengan penerapannya saat proses pembelajaran berlangsung. Rata-rata persentase untuk aktivitas siswa dalam proses pembelajaran Kumon yaitu $92.14 \%$. Hal ini menunjukkan bahwa aktivitas siswa dalam proses pembelajaran pada kelas eksperimen dalam kategori aktif.

Secara deskriptif hasil belajar siswa melalui perhitungan rata-rata skor pre-test kelas eksperimen dapat dilihat pada tabel berikut:

Tabel 1. Hasil analisis deskriptif pre-test post-test kelas eksperimen

\begin{tabular}{|c|c|c|c|}
\hline \multirow{2}{*}{ No } & \multirow{2}{*}{ Deskriptif } & \multicolumn{2}{|c|}{ Eksperimen } \\
\cline { 3 - 4 } & & Pre-test & Post-test \\
\hline 1 & Mean & 67.60 & 72.99 \\
\hline 2 & Varians & 177.43 & 156.64 \\
\hline 3 & Stand. Dev & 13.32 & 15.07 \\
\hline
\end{tabular}

Berdasarkan Tabel 1 di atas dapat diketahui bahwa pada kelas eksperimen rata-rata skor preetest sebesar 67.60 kemudian setelah dilakukan post-test diperoleh rata-rata skor post-test sebesar 72.99 , artinya terdapat peningkatan hasil belajar secara deskriptif.

Sebelum di analisis secara inferensial untuk melihat efektivitas model pembelajaran terhadap hasil belajar, terlebih dahulu dilakukan uji pra syarat analisis yaitu uji normalitas dan uji homogenitas. Adapun hasil uji normalitas dan uji homogenitas dapat dilihat pada tabel berikut:

Tabel 2. Uji normalitas pre-test

\begin{tabular}{|c|c|c|c|}
\hline \multirow{2}{*}{ No } & \multirow{2}{*}{$\begin{array}{c}\text { Uji } \\
\text { Prasyarat }\end{array}$} & \multicolumn{2}{|c|}{ Ekperimen } \\
\cline { 3 - 4 } & $D_{\text {hitung }}$ & $D_{\text {tabel }}$ \\
\hline 1 & Pre-test & 0.132 & 0.338 \\
\hline 2 & Post-test & 0.115 & 0.338 \\
\hline
\end{tabular}

Jika $D_{\text {hitung }}>D_{\text {tabel }}$ maka data tidak berdistribusi normal sedangkan jika $D_{\text {hitung }}<D_{\text {tabel }}$ maka berdistribusi normal. Dari tabel 2 bahwa hasil uji normalitas dengan Kolmogorov Smirnov di atas kelas berdistribusi normal yang dapat ditunjukan dengan $D_{\text {hitung }}<D_{\text {tabel }}$.

Selanjutnya Karena telah memenuhi syarat yaitu berdistribusi normal selanjutnya dilakukan uji hipotesis dengan menggunakan Paired T-test untuk melihat peningkatan hasil 
belajar sebelum dan setelah menggunakan model pembelajaran kumon terhadap hasil belajar siswa. Adapun hasil uji Paired sampel T-test Diperoleh $t_{\text {hitung }}=(4.79)$ dan $t_{\text {tabel }}(1,76)$. Karena nilai $t_{\text {hitung }}(4.79)>t_{\text {tabel }}(1,76)$ dengan demikian maka $\mathrm{H}_{0}$ ditolak, dan secara otomatis $\mathrm{H}_{1}$ diterima dengan kata lain model pembelajaran Kumon efektif terhadap peningkatan hasil belajar matematika siswa kelas VIII SMP Negeri 05 Poleang Timur.

Berdasarkan deskripsi dan analisis data yang telah diperoleh, dapat dijelaskan pada kelas VIII sebagai kelas eksperimen telah melakukan pretest dengan menjawab 5 butir soal Essay. Pretest dilakukan untuk mengetahui skor awal siswa sebelum diberi perlakuan. Melalui hasil pretest di kelas eksperimen diperoleh rata-rata 67.60 dengan kategori cukup baik. Sedangkan melalui hasil postest, diketahui bahwa hasil belajar kelas eksperimen setelah diberi perlakuan dengan model pembelajaran kumon meningkat menjadi 72.99 dengan kategori baik.

Peningkatan hasil belajar dan keaktifan siswa melalui model pembelajaran kumon ditunjukkan dengan siswa antusias mengikuti pembelajaran seperti siswa lebih fokus mengikuti kegiatan pembelajaran, siswa tidak lagi melakukan aktivitas diluar pembelajaran, siswa semangat mencari jawaban dan berani menjawab pertanyaan tanpa dipanggil terlebih dahulu namanya kemudian menjelaskan kepada teman-temanya didepan kelas.

Pada model pembelajaran kumon guru berperan sebagai perancang pembelajaran hal ini sejalan yang disampaikan oleh Peterson dalam Jusman (2014: 9) bahwa guru berperan sebagai perancang pembelajaran, pengelola pembelajaran, penilai hasil pembelajaran siswa, pengarah pembelajaran dan pembimbing siswa. Dalam hal ini seorang guru harus kreatif dalam merencanakan pembelajaran agar siswa menjadi aktif dan kreatif serta inovatif dalam setiap pemecahan masalah yang dihadapi di Sekolah sehingga dapat meningkatkan prestasi belajarnya.

Hal yang telah diuraikan diatas didukung oleh kelebihan dari model pembelajaran kumon seperti yang disampaikan oleh (Shoimin \& Aris, 2014: 95) yaitu 1) Sesuai dengan kemampuan karena sebelum siswa belajar ada tes penempatan sehingga siswa tidak merasa tersiksa; 2) Bahan pelajaran tersusun atas langkah-langkah kecil sehingga siswa bisa memperoleh kemampuan dasar yang kuat; 3) Siswa mengerjakan soal secara mandiri dari tingkat yang mudah sampai tingkat yang lebih sulit bila mengalami kesulitan bisa melihat buku penyelesaian sehingga pembelajaran akan lebih bermakna; 4) Mengajak siswa disiplin.

\section{KESIMPULAN}

Berdasarkan hasil penelitian dan pembahasan dapat diketahui hasil belajar dan keaktifan siswa dengan model pembelajaran kumon nilai post-test lebih tinggi daripada nilai pre-test, maka dapat disimpulkan bahwa model pembelajaran kumon efektif dan dapat digunakan dalam pembelajaran. Berdasarkan kesimpulan di atas, maka peneliti menyarankan kepada guru diharapkan mempunyai pengetahuan dan kemampuan yang cukup untuk memilih model pembelajaran yang tepat dan sesuai dengan materi yang akan diajarkan sehingga dapat meningkatkan hasil belajar siswa. Pada pembelajaran matematika, model pembelajaran kumon dapat digunakan sebagai alternatif pembelajaran untuk meningkatkan hasil belajar matematika. Bagi peneliti yang hendak mengembangkan penelitian ini, dapat melakukannya pada materi lain dalam upaya meningkatkan hasil belajar matematika siswa.

\section{DAFTAR PUSTAKA}

Arikunto, Suharsimi. 2009. Dasar-dasar Evaluasi Pendidikan. Jakarta: Bumi Aksara

Anca. 2015. Penerapan model pembelajaran Kumon menghasilkan kemandirian dan prestasi belajar matematika yang lebih baik dibandingkan dengan penerapan metode ekspositori 
https://jurnal.unsulbar.ac.id/index.php/saintifik

pada siswa kelas VII SMP Takhassus Nuril Anwar Loano Purworejo tahun ajaran 2015/2016. Purworejo: Skripsi tidak diterbitkan

Hamdani. 2011. Strategi Belajar Mengajar. Bandung: Pustaka Setia.

Irianto, A. 2004. Statistik Konsep Dasar dan Aplikasinya. Jakarta: Kencana Prenada Media Group.

Kadir. 2015. Statistika Terapan. Jakarta: Raja Grafindo Persada.

Nasrum, Akbar. 2017. Statistical Determination of Kolmogorov-Smirnov (D) by Using Manual Way. Journal. Vol. 2, No. 2, July 2017. ISSN: 2541-6723.

Nuharini, Dewi, dkk. 2008. Matematika konsep dan aplikasinya untuk SMP/MTSkelas VIII. Jakarta: Departemen Pendidikan Nasional.

Shoimin, Aris. 2014. Model Pembelajaran Inovatif dalam kurikulum 2013. Jakarta : Ar-Ruzz Media.

Slavin, RE. 1994. Educational Pshycology Theory and practice, Fourth Edition Massachusetts. Allyn and Bacon Publisher.

Sudjana. (2005). Metode Statistika. Tarsito: Bandung.

Sugiyono. 2011. Metode Penelitian Pendidikan Pendekatan Kuantitatif, Kualitatif. Bandung: Alfabeta.

Sugiyono. 2015. Metode Penelitian Kuantitatif, Kualitatif, dan Kombinasi (Mixed Methods. Bandung: Alfabeta, cv.

Suherman, Erman. 2003. Strategi Pembelajaran Matematika Kontemporer. Bandung: JICA.

Sukardi. 2003. Metodologi Penelitian Pendidikan Kompetensi Dan Praktiknya. Jakarta: PT Bumi Aksara. 